\title{
CУCПIIIU/HO-ГEOГPADIЧHII DOCRIOKEHHH
}

УДК 911.375.3+502.1

\section{А.А. Мозговий \\ КОНФЛІКТОГЕННІСТЬ МІСЬКОГО ПРОСТОРУ: МЕТОДОЛОГІЯ ДОСЛІДЖЕННЯ}

\begin{abstract}
А.А.Мозговой
КОНФЛИКТОГЕННОСТЬ ГОРОДСКОГО ПРОСТРАНСТВА: МЕТОДОЛОГИЯ ИССЛЕДОВАНИЯ

Институт географии Национальной академии наук Украины, Киев

В статье раскрыты общественно-географические особенности развития городского пространства как сложной территориальной системы. Освещены основные противоречия, возникающие в процессе социально-экономического, территориального, демографического и функционального развития города, приводящие к наращиванию потенциала конфликтного взаимодействия. Предложено определение конфликтогенности развития городского пространства и основные подходы к его общественно-географическому изучению.
\end{abstract}

Ключевые слова: город; городское пространство; городское развитие; конфликт; конфрликтогенность.

\begin{abstract}
A.A.Mozgovyi
CONFLICTOGENIC NATURE OF URBAN SPACE: RESEARCH METHODOLOGY

Institute of Geography of the Ukraine National Academy of Sciences, Kiev

The article reveals the social and geographical characteristics of the urban space development as a complex territorial system. Main contradictions arising in the process of socio-economic, territorial, demographic and functional city development, leading to conflict interaction potential build-up have been highlighted. The urban space conflictogenity definition and main approaches to its socio-geographical study has been presented.
\end{abstract}

Keywords: city; urban space; urban development; conflict; conflictogenity.

\section{Актуальність теми дослідження та стан вивченості питання}

Розвиток міського простору сприймається нині як багатовимірний. Його прояви різноманітні, часто латентні й різноспрямовані. Вони втілюються як у територіальній експансії міст і поширенні меркантилістського міського способу життя за адміністративні міські межі, так і набувають часто «нематеріального виміру» у вигляді, наприклад, інформаційного домінування міст. Якщо розглядати міський простір як складову частину географічного простору, то неминуче виникає разючий дисонанс між тією мізерною площею нашої планети, що припадає на міста, та їхнім визначальним впливом на розвиток цивілізації.

Нині вже є очевидним, що міста перетворились на основну форму осілого розселення на планеті. Також можна говорити, якщо триватимуть тенденції сьогодення, про поступове «витіснення» містами інших форм розселення (рурального і непостійного) з територіальної організації суспільства. Причому це підтверджується не тільки виходячи 3 вищевикладених суджень, але й, 3 недавнього часу, статистично. Так, за даними Фонду народонаселення ООН (UNFPA) [7], від 2008 р. більшість населення нашої планети мешкає в містах. Це сталося вперше в історії людства і на наших очах.
Впродовж усієї історії людської цивілізації процес міського розвитку супроводжувався суперечностями, часто перетворюючись на їхню найгострішу форму - конфлікт.

Онтологія конфлікту здавна цікавила фахівців різного профілю: у першу чергу філософів, а також психологів, соціологів, політологів, культурологів та представників багатьох інших гуманітарних галузей знань. Особливе місце у вивченні природи конфліктів посідають математичні вишукування, зокрема в галузі теорії ігор. Певна розпорошеність та різнорідність наукового знання про природу конфліктів невипадково викликала потребу в його узагальненні та систематизації.

Отже, на певному етапі розвитку науки виникла нагальна потреба в розробці єдиного вчення про конфлікт. Першою спробою зробити це прийнято вважати працю американського вченого Кеннета Боулдінга «Конфлікт і захист: загальна теорія» [22], в якій він виклав основні положення своєї концепції «Загальної теорії конфлікту». На думку вченого, конфлікт $\epsilon$ всезагальною й універсальою категорією, що має однакові етапи, функції та способи розв'язання незалежно від середовища та умов виникнення. Хоча цю ідею було запропоновано науковій громадськості ще 
півстоліття тому, змушені констатувати, що формування «Загальної теорії конфлікту» не мало значних результатів і триває досі.

Дещо пізніше західних досліджень в галузі теоpiї конфліктів, проте значною мірою незалежно від них, серед пострадянських наукових кіл набуває популярності міждисциплінарний напрям досліджень, що отримав назву «конфліктологія». Цей термін не вживають західні науковці, це є результат творчості, в більшості своїй, російських авторів. Можна припустити, що конфліктологія виникла в результаті наукових пошуків- відповідей на виклики часів занепаду радянської системи - деволюційні рухи та численні етнополітичні конфлікти на теренах стагнуючої тоталітарної держави. Конфліктологія мала доволі поживний грунт для свого розвитку і пізніше - в пострадянських реаліях новоутворених незалежних держав як міждисциплінарний напрям дослідження конфліктів.

Проте, принагідно зауважимо, що досі не існує загальновизнаного уявлення про предмет конфліктології. У цій науковій розвідці ми спираємося на визначення М.І. Пірен, за якою «конфліктологія ие наука про зіткнення, проблемне функціонування особи, людського суспільства, природи, про взаємодію людини і природи» [10].

Для вітчизняної географії конфліктологічна проблематика, на відміну від західних географічних шкіл, $є$ порівняно новою. Протягом останніх двох десятиріч на пострадянських просторах відбулося кілька наукових географічних форумів, які були присвячені теоретико-методологічним та прикладним аспектам наукового напряму, що набув назви «геоконфліктологія». Основну увагу при цьому було приділено географічним чинникам виникнення конфліктів, просторовій еволюції та організації конфліктів, типізації конфліктів 3 географічних позицій. Особливої актуальності на межі тисячоліть набули дослідження конфліктів, що розгортаються в суспільно-територіальних системах різного рангу.

Актуальність цього напряму географічних досліджень була неодноразово підтверджена в доповідях провідних географів під час Міжнародного географічного конгресу (ФРН, м. Кельн, 26-30 серпня 2012 р.), де тема ризиків і конфліктів у сучасному глобалізованому світі була винесена в ряд ключових [23].

Оцінюючи розвиненість географічних досліджень конфліктів за допомогою галузево-наукового підходу, стає очевидним, що найбільшого розвитку тема конфліктів набула в політичній географії та геополітиці, де вона активно опрацьовується протягом кількох десятиріч. Проте вивчення різних аспектів конфліктної взаємодії об’єктів у географічному середовищі представниками згаданих напрямків здійснюється, головним чином, на рівні значних територій та ареальних форм просторової організації, в той час як конфліктам в масштабах окремих поселень або їх груп, на нашу думку, не приділено належної уваги.

Географічне дослідження конфліктів не обмежується нині тільки сферами політичної географії та геополітики. Дедалі більшої актуальності набувають географічні дослідження конфліктів у галузі природокористування, вдосконалюються способи їх картографування. Аксіомою є те, що при природокористуванні завжди виникає конфліктна ситуація. Вона знаходить свій вияв у різних аспектах: економічних, соціальних і особливо екологічних [19].

Тема конфліктів міського розвитку в географії населення залишається практично недоторканою. У зв'язку з цим, особливий науковий інтерес викликають дослідження конфліктогенних просторів професора Фрайбурзького університету (Німеччина) Йорга Штадельбауера [21].

На його думку, до умов виникнення та розвитку конфліктів у мегамістах (понад 5 млн мешканців) можна віднести: вразливість міської системи в глобалізованому світі; концентрація політичних та економічних функцій; протиріччя планування; щоденні конфлікти міського життя; зниження соціального контролю та криміналітет; соціальна фрагментація та соціально замкнені спільноти; якість життя й навантаження на середовище; проблеми водопостачання, видалення та переробка відходів; вразливість населення перед природними катаклізмами.

Зауважимо, хоча вчений вивчав проблеми конфліктогенних просторів на прикладі мегаміст, проте більшість 3 вищеперелічених суперечностей можна сміливо екстраполювати на міський розвиток загалом.

Метою цієї публікації є виявлення питомих рис розвитку міського простору, визначення поняття конфліктогенності міського розвитку та окреслення основних підходів до його суспільногеографічного вивчення.

\section{Виклад основного матеріалу}

Проблематика розвитку міського простору охоплює широке коло теоретичних і прикладних питань, дослідження яких грунтується на таких концептах та базових наукових категоріях як «система», «розвиток» та «простір». Географічний зміст кожного $з$ них наповнений множиною понять, термінів та причинно-наслідкових зв'язків. Географічні об'єкти як територіальні системи мають неабиякий потенціал розкриття змісту цих базових наукових категорій. Яскравим прикладом таких територіальних систем $є$ місто.

Очевидним є те, що за своєю природою та характером функціонування місто має системний 
характер. Серед численних ознак складної системи в науковій літературі найчастіше згадуються відкритість такої системи, її здатність до саморозвитку та самоорганізації. Усі ці риси притаманні системі міста: по-перше, місто завжди було і $є$ відкритою системою, фактично «системою в системі»-в системі поселень; по-друге, будь-якому місту властиві саморозвиток й самоорганізація, тому що саморозвиток закладено в самій сутності міста.

Місто як «рушій прогресу» не можна уявити статичним, воно має розвиватись, розвиваючи прилеглі території. Саморозвиток конкретного міста зумовлюється як внутрішніми чинниками, так i зовнішніми впливами, які можна розглядати як прояви саморозвитку систем поселень, радше, систем розселення вищого рівня (регіональних, національних). Тому дуже важко дослідити процеси і визначити напрямки розвитку міста, чи навіть категорії міст, не врахувавши системності їх існування

Крім того, місто зі складними системами споріднює також його структурна, функціональна та динамічна складність, що зумовлено значною концентрацією об'єктів, які взаємодіють на обмеженій території. Проте, на різних етапах розвитку суспільства характер взаємодії між об'єктами може бути різним.

Динамізм функціонування міста, зокрема, проявляється: в рухах потоків населення 3 приміської зони до місць роботи вранці і відтоку населення ввечері (маятникова міграція); в активному переміщенні власне міських жителів протягом дня, в пов'язаних 3 цим піках транспортної напруженості; в ритміці роботи виробництв та установ, або в безперервності їх роботи; в цілодобовості життєзабезпечення міста (водо- та енергопостачання, сміттєвивезення та ін.).

Розвиток міста, як наслідок динамізму функціонування, проявляється також у постійному будівництві, переплануванні вулиць, прокладанні нових комунікацій та адаптації міського середовища до нових умов загалом.

Географія як наука-інтегратор має неабиякий методичний апарат для дослідження міської системи. Нині у вітчизняній суспільній географії в якості загального означення системних об'єктів найчастіше використовують поняття «суспільнотериторіальна система», що об'єднує виробничі, соціальні, населенські або природні елементи. При дослідженні окремих елементів суспільнотериторіальної системи на перший план виступають їхні функції. Подібні утворення мають свою систематику i, таким чином, «конкретними типами суспільно-територіальних систем є виробничо-територіальні комплекси і системи, територіальні системи розселення, територіальні рекреаційні системи, транспортні системи регіонів, міста» [8].
Територія як просторова передумова цивілізаційних процесів є базовою категорією географічної науки. Як природно-територіальні, так і суспільнотериторіальні системи неможливі поза «місцем». Територіальність є однією 3 найважливіших ознак подібних утворень. Хоча сучасні міста переважно лишаються, радше, дискретною формою територіальної організації суспільства, однак вони теж складаються 3 окремих територіальних частин (підсистем), а також є територіальними складовими масштабніших географічних об'єктів. Елементам суспільно-територіальної системи міста притаманні такі територіальні параметри, як різний ступінь доступності, територіальна конфігурація, територіальна концентрація та інші.

Вочевидь, що згадані територіальні параметри істотно впливають на розвиток конкретного міського поселення.

Отже, спираючись на вищевикладене, спробуємо окреслити основні особливості міського розвитку. Виходячи з загальнонаукового сучасного уявлення про розвиток [19], під міським розвитком ми розумісмо незворотні, закономірні й спрямовані зміни суспільно-територіальної організаціїміського простору.

Цей процес супроводжується постійною трансформацією поселенської мережі 3 переміщенням населення в міста та істотною зміною способу його життя.

Розглянемо докладніше кожну 3 питомих рис міського розвитку.

Так, незворотність змін характеризує функціонування міської системи, тобто циклічну і динамічну роботу функцій міста. Набір функцій міста, на нашу думку, відповідно до логіки розвитку, повинен проходити стадії від комплексу до системи. Наукове пояснення незворотності як риси міського розвитку має певні застереження. 3 історичної географії достеменно відомою $є$ маса прикладів «перетворення» міських поселень на сільські, тобто прикладів деградації міського середовища, i це може свідчити, на перший погляд, про певну «зворотність» міського розвитку. Хибність такого пояснення полягає в тому, що перехід населеного пункту 3 категорії «міст» до категорії «сіл» свідчить, насправді, не про зворотність розвитку, а, навпаки, підтверджує його незворотність.

Адже розвитку міста, як і будь-якої складної територіальної системи, властива еволюційна стадійність: міста зароджуються, зростають, досягають розквіту, занепадають й, з рештою, зникають. При перетворенні міста на село населений пункт «за інерцією» може ще деякий час зберігати за собою адміністративний статус міста, хоча його мешканці вже поколіннями ведуть руральний спосіб життя. Ця проблема - якісного розмежування міського 
і сільського середовищ - лишається ще доволі слабо розкритою в сучасній науці.

Спрямованість змін суспільно-територіальної системи міста визначає єдність розвитку міста, що надає йому рис внутрішньої взаємозалежності - траєкторії міського розвитку. Напрям змін суспільно-територіальної системи міста, як правило, пов'язаний з ускладненням структури господарства, збільшенням масштабів його економічного, соціального та екологічного впливу на прилеглу територію, появою нових елементів i функцій структури.

Саме у зв'язку з простеженням спрямованості розвитку певного міста найчастіше можна зіткнутись 3 оцінковими судженнями окремих фахівців та громадськості щодо розвитку міста; йдеться про основні його тенденції - прогрес і регрес. Прогресивний розвиток міст, тобто напрям розвитку від «гіршого» до «кращого», досить тривалий історичний час був «наріжним каменем» міського управління й міської політики в Європі. Через європейський універсалізм загальна теорія прогpecy і прогресивності міста була поширена на глобальному рівні.

Проте 3 другої половини XXст., коли негативні наслідки урбанізації, індустріалізації, технізації та інтернаціоналізації світового господарства стали очевидними, теорія прогресу стала піддаватись жорсткій критиці з боку громадськості. Нині «прогресивність» всього міського не є вже такою беззаперечною.

Закономірність змін суспільно-територіальної системи міста передбачає суттєвий і постійно повторюваний взаємозв'язок елементів міської системи, визначальних етапів і форм процесу міського розвитку. Можна виділити загальні й одиничні, тобто універсальні та специфічні закономірності міського розвитку. Але це предмет окремого дослідження. Вважаємо, що закономірність є тією властивістю міського розвитку, що вирізняє його від змін катастрофічного характеру.

Очевидно, що навіть вичерпна характеристика окремих властивостей міського простору не створить наукової картини його розвитку. Вочевидь, процес міського розвитку має свою систематику, тобто певну видову структуру.

При більш наближеному розгляді цього питання ясно проступають принаймні чотири види міського розвитку, а саме: територіальний, демографічний, соціально-економічний та функціональний розвиток.

Територіальний розвиток міста проявляється в територіальній експансії міської забудови і комунікацій на прилеглу місцевість. Якщо античне чи середньовічне міське середовище обмежувалось оборонними мурами й рідко «виплескувалось» за їхній периметр, то територіальне зростання сучасних міст $€$ безпрецедентним, наприклад недавні зміни адміністративних меж Москви, коли площа цього міста зросла майже втричі.

Територіальна експансія міст часто $є$ невиправданою, особливо постсоціалістичних, адже досі «значні площі центральної частини міст зайняті землями промисловості, оборони, енергетики, а також садибною забудовою, що інвестиційно не виправдано» [9]. Територіальний «прогрес» міста, особливо великого, завжди призводить до деградації прилеглої сільської місцевості та природного середовища. Вздовж основних транспортних магістралей, далеко за адміністративні межі сучасного великого міста розростаються «язики субурбанізації» - суцільно організована територія, колишня сільська місцевість, мешканці якої ведуть урбаністичний спосіб життя й абсолютно відірвані від традиційного культурного субстрату села.

Окремою проблемою територіального «прогресу» сучасних міст $\epsilon$ поширення так званих «котеджних містечок», яких тільки в передмістях сучасного Києва нараховується близько чотирьох десятків. Ці соціально замкнені «виплески капіталу» великого міста територіально віддалені від нього, але ще більше вони дистанційовані в інформаційному, культурному та ментальному відношеннях від середовища свого розташування. Фактично йдеться про однобічний утилітарний зв'язок: споживацьке відношення й виснаження природних ресурсів сільської місцевості з боку мешканців такого містечка, а наслідками є відходи життєдіяльності, техногенне забруднення й сміття.

Демографічний «прогрес» міста проявляється, в першу чергу, в зростанні чисельності його населення. Оптимальної чисельності населення міста не існує, хоча не так давно науковці робили спроби іiї встановити. Очевидним $\epsilon$ те, що число міських мешканців дуже швидко долає «раціонально встановлені» і «науково обгрунтовані межі», а геодемографічні процеси відбуваються за своїми законами. Деяким державам вдається адміністративними методами регулювати чисельність міського населення (КНДР, КНР, колишній СРСР), проте це потребує встановлення тоталітарного політичного режиму і суперечить правам людини.

Негативними наслідками демографічного «прогресу» $є$ такі явища як псевдоурбанізація та прихована урбанізація. Суть їх полягає в нерегульованій і неконтрольованій масовій міграції сільських мешканців до міст. Це населення прагне покращення якості життя, але не забезпечується в місті ні належними умовами проживання, ні гідною оплатою праці, ні соціальним гарантіями. Це при- 
зводить до маргіналізації та криміналізації цілих районів і передмість, неінтегрованості й соціальної замкненості таких спільнот.

Отже, основна загроза територіального та демографічного «прогресу» міст полягає навіть не у вилученні нових земель, скажімо, із сільськогосподарського вжитку та зменшенні частки сільських мешканців певної території, а в скороченні простору формування традиційної культури й припиненні трансляції етнічних культурних кодів в колишній сільській місцевості, адже велике місто - це культурний конгломерат, що не має етнічності.

«Прогресивний» соціально-економічний розвиток міста проявляється в зростанні кількісних показників, що нерідко призводить до погіршення екологічних властивостей природи. Зазначимо, що нині «існуючому протиріччю між економічним зростанням і збереженням біосфери, що забезпечує виживання людства, немає розв'язання» [16].

Прискорений соціально-економічний розвиток міст, порівняно з руральними просторами, найчастіше пов'язують 3 такою його властивістю як урбаністична концентрація. Це фундаментальна ознака міста, що полягає в значній щільності на обмеженій території різноманітних об'єктів і видів діяльності, які перебувають у постійному взаєморозвитку та взаємозалежності. 3 іншого боку, в близькому сусідстві знаходяться окремі об'єкти, що тяжіють до міста, але є несумісними. Наприклад, перевантаження міського простору об'єктами промисловості, що завжди призводить до погіршення екологічної ситуації i, відповідно, якості життя населення.

Територіальна концентрація хоч і дає можливість отримати значний економічний ефект, проте нерозривно пов' язана з цілим рядом побічних негативних наслідків і факторами ризику для людини, серед яких виділяють такі: «надмірна кількість мешканців і рівень концентрації населення; розміщення населення, яке підпадає під загрозу бути в зоні ураження; а також насиченість міста елементами техногенної інфраструктури (промислові та житлові споруди, системи транспорту та комунікацій)» [4].

На нашу думку, найбільш коректними індикаторами соціально-економічного «прогресу» міського розвитку є параметри якості життя містян. Саме через комплексне дослідження категорії якості життя населення розкриваються такі поняття як спосіб життя, рівень життя та стиль життя мешканців населеного пункту [3]. Динаміка якості життя мешканців $є$ головним індикатором соціальноекономічного розвитку міста i, одночасно, передумовою його перспективного розвитку, що зумовлює «привабливість» певного міста для праці та проживання.
Функціональний розвиток міста проявляється в перманентній трансформації його функціональної структури та розширенні спектра виконуваних функцій. Виходячи 3 цього, «прогрес» функціонального розвитку розуміємо як розширення переліку виконуваних містом функцій, відповідно «регрес»- розвиток в бік монофункціональності.

До переліку основних функцій, що формують «обличчя» міста як територіального локусу людської культури, найчастіше відносять наступні: демографічну, виробничу, адміністративно-управлінську, комплексну соціальну (культурно-освітню, охорони здоров'я, комунально-господарську та ін.), торговельну, транспортну та рекреаційну. Цей приблизний перелік міських функцій, на нашу думку, відображає основні сфери життєдіяльності містян та сутнісно розкриває особливості міського середовища - середовища цивілізаційного поступу. Кожна 3 міських функцій $є$ багатоваріантною за формою та інтенсивністю свого прояву, проте в різних природних та суспільних умовах зміст їх залишається незмінним.

Місту взагалі властива така фундаментальна риса як багатофункціональність, яку ми розуміємо не тільки у виробничому аспекті, а ширше, охопивши всі види людської діяльності. Кожне, навіть найменше, місто з периферійного сільського району, що не має виробничої багатофункціональності та розвиненої інфраструктури, залишається втіленням багатофункціональності цілого району, що його оточує, виконуючи управлінські, торговельні, культурні, освітні та інші функції.

Місто не може існувати без свого оточення. Воно пов'язане $з$ ним, використовує ресурси оточуючого району, має обслуговувати цей район, а для цього його функціональна структура повинна бути розвиненою.

Отже, багатофункціональність - це не просто ознака, це призначення міста.

Багатофункціональність дозволяе повніше використовувати елементи потенціалу міста: географічне положення, специфічне середовище, розвинену інфраструктуру, кваліфіковані кадри, виробничі фонди тощо. Але, з іншого боку, розвиток функцій міста безпосередньо зумовлюється його потенціалом.

Принагідно зазначимо, що потенціал міського розвитку - це сукупність наявних можливостей використання елементів цілісної суспільно-територіальної системи населеного пункту для потреб територіального, демографічного, функціонального та соціально-економічного розвитку міста. Структура потенціалу міського розвитку може включати кілька основних елементів.

Потенщіал суспільно-географічного положення міста - це сукупність можливостей впливу по- 
ложення міста в географічному просторі на його розвиток. Цей вплив може бути розкрито застосуванням порівняльно-географічного методу при вивченні таких властивостей суспільногеографічного положення міста як доступність, детермінованість, потенційність. Крім чинників суспільного положення, цей потенціал безпосередньо пов'язаний з його знаходженням у певній фізико-географічній зоні, з кліматичними умовами, водозабезпеченістю, екологічною ситуацією тощо.

Людський потениіал міста - це кількість і якість людських ресурсів з урахуванням можливостей їх кількісного і якісного зростання та використання при виконанні певних його функцій. Тенденції динаміки народонаселення визначають чисельність людських i трудових ресурсів, його соціальний склад, зайнятість, що, у свою чергу, впливає на соціально-економічний розвиток.

Інфраструктурний потенціал міста можна визначити як сукупність можливих і перспективних елементів виробничої, соціальної та екологічної інфраструктури, які використовуються або можуть бути використані у виробництві та спрямовані на підвищення продуктивності суспільної праці і якості життя населення.

Інформаційний потенціал міста - це наявні й ті, що можуть бути задіяні обсяги інформаційних ресурсів, інформаційної техніки і технологій, а також збору, накопичення, обробки та використання різних форм інформації для задоволення відповідних потреб міської громади.

Природно, що представлена вище структура потенціалу міського розвитку не $\epsilon$ вичерпною і потребує подальшого наукового вивчення. При цьому важливим $\epsilon$ розкриття змісту понять «міський простір» та «міський просторовий розвиток».

У нашому дослідженні ми використовуємо такий понятійно-їєрархічний ряд: «простір» «географічний простір» - «міський простір».

Географічний простір (геопростір) у сучасній українській географічній науці розуміють як «множину географічних об'єктів, які мають своє місцеположення, та множину відношень між ними» [17].

Виходячи з того, що «територіальність, прив'язка до території $\epsilon$ прямою ознакою географічних досліджень і географічних об'єктів, суміщення і накладання різних видів простору очевидне» [18], тому міський простір ми розглядаємо як складову географічного простору.

Питання просторового розвитку, в тому числі й міського, що грунтується на принципах «збалансованого просторового розвитку», відображені в основній парадигмі XXI століття - сталого збалан- сованого економічного, соціального та екологічного розвитку. Дослідження проблем сталого розвитку населених пунктів, особливо міст, є нині одним iз стрижневих напрямів наукового обгрунтування планетарної концепції сталого розвитку.

3 одного боку, стійкість розвитку населених пунктів часто $є$ однією з провідних тем при обговоренні в наукових колах можливостей глобального переходу сучасної цивілізації до моделі сталого розвитку. Концепція сталого розвитку населених пунктів розвинулася в самостійну галузь, як теоретичної, так і прикладної спрямованості, що сприймається нині науковою громадськістю як природна і невід'ємна частина парадигми сталого економічного, соціального та екологічного розвитку нашої планети.

Зауважимо, що концепція сталого розвитку населених пунктів не завжди посідала те гідне місце серед різних аспектів сталого розвитку, яке належить їй сьогодні. Зі Стокгольмського саміту 1972 аж до Хабітат II в 1996 р. питання сталого розвитку населених пунктів перебували на периферії уваги міжнародної наукової громадськості. Хоча сприянню сталому розвитку населених пунктів у «Порядку денному на XXI століття» присвячено окремий розділ [12], однак документ не містить визначення цього поняття і присвячений переважно питанням ефективного управління i планування розвитком населених пунктів. Більше того, «Йоганнесбурзька декларація зі сталого розвитку» [5] як і «План виконання рішень» [11], прийняті на Йоганнесбурзькому саміті в 2002 р., також не містять його серед положень, пов'язаних зі сталим розвитком населених пунктів.

Сьогодні ця проблема набуває нової смислової наповненості - в часи, коли відбувається становлення нового планетарного етапу урбанізації та глобальної трансформації способу життя людства.

Підсумковий документ Конференції ООН зі сталого розвитку «Майбутнє, якого ми хочемо» (2022 червня 2012 р., м. Ріо-де-Жанейро, Бразилія) в розділі «Рамкова програма дій та наступні заходи» містить окремий розділ «сталі міста і населені пункти» (пп. 134-137). У документі відзначено «необхідність застосування цілісного підходу до урбанізації та розвитку населених пунктів» [1].

Переходячи від загальних питань міського розвитку до національного рівня дослідження, зауважимо, що Україна є сьогодні високоурбанізованою країною. Хоча за офіційними даними в міських поселеннях нашої країни проживає $68,77 \%$ населення (на 01.01.2012р.) [20], цей показник не відображає реальних наслідків урбанізації, тому що спирається на формальну ознаку адміністративної реєстрації місця проживання громадян. За експертними оцінками, рівень урбанізованості України давно вже досяг 75\%, тобто фактично країна 
за цим показником знаходиться в числі найбільш урбанізованих.

Природно, що і всі проблеми, і всі негативні наслідки урбанізації мають гострий прояв в Україні.

Оцінюючи результати виконання Україною завдань, визначених «Порядком денним на XXI століття», необхідно відзначити, що цілі щодо забезпечення населення належним житлом не було i, вочевидь, не буде досягнуто в найближчому майбутньому [13].

Можна також констатувати відсутність істотного прогресу в сприянні раціональному територіальному плануванню в містах, а також у створенні належної інфраструктури в галузі охорони навколишнього природного середовища до 2025 р. [13]. Тому небезпідставними є побоювання, що рішення підсумкових документів Ріо+20 стосовно сталих міст не будуть реалізовані в Україні навіть у найближчі десятиріччя.

Однак, ми можемо говорити і про деякі зрушення в реалізації глобальних рішень на національному рівні. Хоча в Україні протягом двадцяти років, що минули з часу першої конференції ООН зі сталого розвитку, так і не була прийнята національна стратегія сталого (збалансованого) розвитку, однак основні положення сталого розвитку України вже опрацьовані й узагальнені науковцями й громадськими діячами, що відображено у відповідній монографічній праці [6].

У державній «Концепції сталого розвитку населених пунктів» зафіксовано визначення сталого (збалансованого) розвитку населених пунктів. Відповідно до цього нормативного документа, під сталим розвитком населеного пункту слід розуміти «соціально, економічно і екологічно збалансований розвиток міських і сільських поселень, спрямований на створення їх економічного потенціалу, повноцінного життєвого середовища для сучасного і майбутніх поколінь на основі раціонального використання ресурсів...» [14].

Отже, законодавче визначення сталого розвитку населених пунктів базується на ресурсному підході, що значно звужує його зміст і призначення.

На нашу думку, сталий міський розвиток - цее сочіально, економічно та екологічно збалансовані зміни суспільно-територіальної системи міста, спрямовані на максимально повну реалізацію всіх складових потенціалу його розвитку $і$ запобігання можливим тенденціям погіршення якості життя населення.

Проте на шляху «прогресивного» розвитку міст $€$ істотна перепона, пов'язана з тим, що в наукових уявленнях сьогодення розвиток складних систем, тобто відкритих і здатних до самоорганізації, є неможливим без суперечностей, які його супровод- жують і зумовлені структурною, функціональною та динамічною складністю цих утворень.

Так, структурна складність систем зумовлює «вертикальні» та «горизонтальні» суперечності між ієрархічно різними елементами; функціональна складність викликає суперечності, пов'язані з якісно різною, а іноді протилежною, спрямованістю процесів функціонування системи; динамічна складність породжує суперечності дисонанснорезонансного характеру, пов'язані з аритмічністю процесів, незбігом їхніх часових параметрів та несинхронізованістю взаємозалежних процесів. Найгострішими проявами таких суперечностей $є$ конфлікти.

У процесі накопичення і узагальнення людством наукового знання стає дедалі очевиднішим, що концепти «розвиток» та «конфлікт» перебувають в діалектичній єдності. 3 одного боку, конфлікт нібито заперечує розвиток, а з іншого, - виступає невід’ємним його атрибутом і навіть необхідною умовою.

Серед усієї множини сучасних наукових визначень конфлікту найприйнятнішим для умов нашого дослідження ми вважаємо таке:

Конфлікт - ие «протидія двох або більше суб'єктів, а іноді проиесів, щзо претендують на зумовлюваний ними стан дійсності» [2].

Конфліктуючими сторонами в міській системі можуть бути суб'єкти господарської діяльності, органи управління, суспільні групи, окремі особи і навіть технічні системи. Конфліктувати між собою можуть навіть різні види розвитку міста, тобто територіальний, демографічний, функціональний та соціально-економічний розвиток.

Окремою проблемою в дослідженні конфліктів міського розвитку є питання про їхню систематику. При всій різноманітності можливих підходів до групування, класифікації й типізації конфліктів міського розвитку в найзагальнішому вигляді їх можна систематизувати за сферами прояву: конфлікти економічні, соціальні та екологічні.

Враховуючи викладене, на цьому етапі дослідження ми пропонуємо під конфліктогенністю міського розвитку розуміти існуючі та можливі екологічні, економічні та сочіальні конфлікти, щуо виникають у прочесі взаємодіі суб'єктів міського розвитку, щзо впливають на стан міського середовища та проявляються через мобілізацію просторових, матеріальних $i$ духовних ресурсів, асиметричність деструктивних дій та наявність згубних наслідків для сторін - носїв інтересів.

Особливо важливою для міського розвитку є та обставина, що кожний конфлікт має як деструктивні, так і конструктивні функції. Так, в процесі конфліктної взаємодії відбувається пошук оптимальних управлінських рішень, реструктуризація території 
міста, реорганізація міського середовища тощо. Проте «конструтивність» і «деструктивність» функцій конфлікту та, особливо, його наслідків мають значний суб'єктивний зміст. Для уникнення суб'єктивізму в подібних дослідженнях пропонуємо розглядати функції та наслідки конфліктів міського розвитку на вищих рівнях територіальної організації суспільства - регіональному та національному. Доцільним також $є$ ширше застосування методу експертних оцінок.

\section{Висновки}

Розвиток міського простору може мати різну спрямованість і залежить від конкретних історичних, економічних та соціальних умов розвитку суспільства, стадії розвитку міста, ступеня реалізації потенціалу розвитку міста, стану взаємодії суспільства і природи та інших умов. Ці умови можуть мати як внутрішньоміський, так i зовнішній характер.

3'ясовано, що при оцінюванні розвитку міста за одновимірною шкалою «регрес-прогрес» істотно зростає проблема дотримання об'єктивності дослідження. За таких обставин потребує ретельнішого опрацювання методика застосування об'єктивних і суб'єктивних індикаторів при дослідженнях міського розвитку, їхнє двомірне співвідношення та зовнішня експертиза.

Очевидно, що прогрес в одному напрямі чи сфері обов'язково породжує конфлікти й регрес в інших сферах міського розвитку.

Нині, як ніколи раніше, основні постулати теоpiї прогресу є хиткими, а впевненість в необхідності подальшого економічного й технологічного зростання є сумнівною.

Дедалі більшої поширеності серед науковців набуває альтернативний теорії прогресу ймовірнісний підхід у розумінні цивілізаційного розвитку людства. Політику індустріалізації, урбанізації та прискореного розвитку великих міст заступила теорія меж зростання і концепція сталого збалансованого розвитку. Проте на шляху іiі реалізації та впровадження існує немало об'єктивних i суб'єктивних перепон, подолання яких потребуватиме значних зусиль людської цивілізації.

Доведено, що конфлікти є не тільки наслідком динамічного міського розвитку, а й необхідною його умовою.

На нашу думку, принциповим нині є усвідомлення серед широких кіл урбаністів неминучості конфліктів у процесі розвитку міста. Конфліктогенність має сприйматись як невід'ємна атрибутивна риса міського розвитку.

Саме через економічні, соціальні та екологічні конфлікти, що виникають у процесі функціонування міської системи, 3“являються можливості й мобілізуються ресурси для розвитку як окремого міста, так і цілих міських мереж. Це стає можливим завдяки ефекту «дифузії інновацій», епіцентром яких майже завжди виступає певне місто.

\section{Лimepamypa}

1. Будущее, котрого мы хотим. Резолюция, принятая Генеральной Ассамблеей ООН 66/288. - NY: UN Distr.: General. - 11.09.2012. - 68 с./ [Електронний ресурс]. - Режим доступу: http://daccess-dds-ny.un.org/ doc/UNDOC/ GEN/ N11/ 476/12/PDF/ N1147612. pdf? OpenElement

2. Всемирная энциклопедия. Философия. - Москва: АСТ, 2001. - 1312 с.

3. Гукалова I.В. Якість життя населення України: суспільно-географічна концептуалізація. - Київ: ДП «Друкарня МВС України», 2009. - $347 \mathrm{c}$.

4. Дронова О.Л. Фактори ризику техногенних надзвичайних ситуацій в Україні. - Київ: Інститут географії НАН України, 2011. $-270 \mathrm{c}$

5. Йоганнесбургская декларация по устойчивому развитию / [Електронний pecypc]. - Режим доступу: http://www.un.org/ru/ documents/decl_conv/ declarations/decl_wssd.shtml

6. Модель сталого розвитку для України: системний підхід, методологія переходу. - Одеса.: УПРЕЕД НАН України, ІГ НАН України, 2012. - 59 с.

7. Народонаселение мира в 2007 году. Использование потенциала урбанизации / Фонд ООН в области народонаселения, Нью-Йорк. - 113 с. / [Електронний ресурс]. - Режим доступу: http://www.unfpa.org/webdav/site/global/shared/documents/ publications/2007/ swp2007_rus.pdf

8. Паламарчук М.М., Паламарчук О.М. Економічна і соціальна географія України з основами теорії. - Київ: Знання, 1998. - 416 с.

9. Палеха Ю.М. Економіко-географічні аспекти формування вартості територій населених пунктів. - Київ: ПРОФІ, $2006 .-340$ с.

10. Пірен М.І. Конфліктологія: Підручник. - Київ: МАУП, 2003. - 360 с.

11. План выполнения решений Всемирной встречи на высшем уровне по устойчивому развитию. - A/CONF.199/20. / [Електронний pecypc]. - Режим доступу: http://www.un.org/russian/ conferen/wssd/docs/plan_wssd.pdf

12. Повестка дня на XXI век. Глава 7. Содействие устойчивому развитию населенных пунктов / [Електронний ресурс]. - Режим доступу: http://www.un.org/ru/ documents/decl_conv/ conventions/agenda21_ch7.shtml

13. Проект доповіді до конференції ООН зі сталого (збалансованого) розвитку Ріо +20 / С.А. Лісовський, Г.Б. Марушевський, П.Г.Павличенко, Л.Г. Руденко, Т.В. Тимочко. - Київ: Центр екологічної освіти та інформації, 2012. -60 с.

14. Про концепцію сталого розвитку населених пунктів: Постанова Верховної Ради України // Офіційний вісник України. - Київ, 2000. - №1. - C. 29-40.

15. Руденко Л.Г., Маруняк С.О. Сучасні просторові дослідження: виклики та відповіді // Український географічний журнал. 2011. - № 3. - C. 38-41. 
16. Руденко Л.Г. Ноосферна філософія В.І. Вернадського - фундамент сталого (збалансованого) планетарного розвитку // Український географічний журнал. - 2013. - № 2. - С. 7-12.

17. Топчієв О.Г. Суспільно-географічні дослідження: методологія, методи, методики. - Одеса: Астропринт, $2005 .-632$ с.

18. Україна: основні тенденції взаємодії суспільства і природи у ХХ ст. (географічний аспект) / НАН України. Інститут географії; За ред. Л.Г. Руденка. - Київ: Академперіодика, 2005. - 320 с.

19. Філософський енциклопедичний словник /Інститут філософії імені Г.С. Сковороди Національної академії наук України. За ред. В. І. Шинкарука. - Київ: Абрис, 2002. - 750 с.

20. Чисельність наявного населення України на 1 січня 2012 року / Державна служба статистики України. - Київ: Інформаційновидавничий центр Державної служби статистики України, 2013. - 112 с.

21. Штадельбауер Йорг. Мегагорода как конфликтогенные пространства // Глобальный город: теория и реальность / Под ред. Н.А. Слуки. - Москва: ООО «Аванглион», 2007. - С. 66-78.

22. Boulding K. E. Conflict and defense: a general theory. - New York: Harper \& Brothers, 1962. - 349 p.

23. IGC COLOGNE 2012 - 32nd International Geographical Congress Cologne/ 26-30 August 2012 / [Електронний ресурс]. - Режим

\section{References}

1. The future, we want. The UN General Assembly Resolution 66/288- NY: UN Distr.: General. - 11.09.2012: http://daccess-dds-ny. un.org/ doc/UNDOC/ GEN/ N11/ 476/12/PDF/ N1147612. pdf?OpenElement

2. World Encyclopedia. Philosophy (2001). Moscow: AST.

3. Gukalova I.V. (2009). Quality of life in Ukraine: social and geographical conceptualization. Kyiv: SE «Publishing of Ukraine MIA.

4. Dronova O.L. (2011). Risk Factors of the technogenic emergencies in Ukraine. Kyiv: Institute of Geography of Ukraine NAS.

5. Johannesburg Declaration on sustainable development: http://www.un.org/ru/documents/decl_conv/ declarations/decl_wssd.shtml

6. Model of Sustainable Development for Ukraine: systematic approach, methodology of transfer (2012). Odessa.: UPREED of Ukraine National Academy of Sciences, IG of Ukraine NAS.

7. State of World Population in 2007. Using the urbanization potential. United Nations Population Fund. New York: http://www.unfpa. org/webdav/site/global/shared/documents/ publications/2007/swp2007_rus.pdf

8. Palamarchuck M.M., Palamarchuck O.M. (1998). Economic and social geography of Ukraine with theory fundamentals. Kyiv: Znannia.

9. Palekha Yu.M. (2006). Economic and geographic aspects of the populated areas costs formation. Kyiv: PROFI.

10. Piren M.I. (2003). Conflictology: Textbook. - Kyiv: AIDP.

11. Implementation Plan of the World Summit on Sustainable Development. A / CONF.199 / 20: http://www.un.org/russian/ conferen/ wssd/docs/plan_wssd.pdf

12. XXI century Agenda. Chapter 7: Promoting sustainable development of human settlements: http://www.un.org/ru/ documents/decl_ conv/conventions/agenda21_ch7.shtml

13. Draft of the presentation to the UN Conference on Sustainable (balanced) development Rio +20. S.A. Lisowski, G.B. Marushevsky, P.G. Pavlychenko, L.G. Rudenko, T.V. Tymochko (2012). Kyiv: Center for Environmental Education and Information.

14. On the concept of human settlements sustainable development: Resolution of the Ukraine Verkhovna Rada (2000). Ukraine Official Bulletin, 1, 29-40.

15. Rudenko L.G., Marunyak Ye.O. (2011). Modern spatial research: challenges and answers. Ukrainian Geographical Journal, 3, 38-41.

16. Rudenko L.G. (2013). Noosphere philosophy of V.I. Vernadsky - the foundation of sustainable (balanced) global development. Ukrainian Geographical Journal, 2, 7-12.

17. Topchiev O.G. (2005). Socio-geographic research: methodology, methods and techniques. Odessa: Astroprint.

18. Ukraine: main trends in society and nature interaction in the twentieth century. (geographical aspect). Under ed. of L.G. Rudenko (2005). Ukraine National Academy of Sciences. Institute of Geography. Kyiv: Academperiodica.

19. Philosophic Encyclopedic Dictionary. Under ed. of V.I. Shynkaruk (2002). Philosophy Institute after G.S. Skovoroda Ukraine National Academy of Sciences. Kyiv: Abrys.

20. Population of Ukraine on 1 January, 2012. Ukraine State Statistics Service. Kyiv: Information and Publishing Center of Ukraine State Statistics Service.

21. Shtadelbauer Joerg (2007). Megacities as conflictogenic areas. Global city: theory and reality. Under ed. N.A. Sluka. Moscow: «Avanglion» LLP, 66-78.

22. Boulding K.E. (1962). Conflict and defense: a general theory. New York: Harper \& Brothers.

23. IGC COLOGNE 2012 - 32nd International Geographical Congress Cologne / 26-30 August 2012: http://igc2012.org/frontend/ index.php 